\title{
A Strategic Approach for Bottleneck Identification in Make-To-Order Environments: A Drum-Buffer-Rope Action Research Based Case Study
}

\author{
Aitor Lizarralde-Aiastui (D), Unai Apaolza-Perez de Eulate iD, Miguel Mediavilla-Guisasola iD \\ Mondragon Unibertsitatea (Spain) \\ alizarralde@mondragon.edu,napaolaza@mondragon.edu,miguel.mediavilla@operations.es
}

Received: March 2019

Accepted: December 2019

\begin{abstract}
:
Purpose: This study focused on providing a strategic perspective for the selection and exploitation of bottlenecks in make-to-order production systems, a largely unexplored field in the literature. The researchers developed a systematic decision-making process that operationalized the first two stages of Goldratt's drum-buffer-rope methodology. This process was derived from the seminal work of Goldratt, who introduced key insights from the resource-based view and practice-based view strategic perspectives. The process also included original contributions from the authors to understand which purpose should be fulfilled, what decisions should be made and how the process should be applied in an operative way.
\end{abstract}

Design/methodology/approach: Given the practical nature of the research project, action research was an appropriate methodological approach, since this approach aims to contribute to academic research while solving real-world problems. Additionally, the research process complied with necessary criteria to assure the research quality required for action research.

Findings: The systematic process was successfully tested by means of a case study on a make-to-order company. This case study answered the research question regarding systematically selecting and exploiting a bottleneck to enhance competitive advantage/firm performance.

Originality/value: The key contributions focused on the make-to-order environment and were as it follows: (1) four specific criteria to select the bottleneck, far beyond a load versus capacity perspective (i.e., a strategic perspective inspired by the main concepts of the resource-based view regarding the contribution of strategic resources to sustain competitive advantage). A first case study presenting a partial version of this contribution has been discussed on a previous publication of the authors (Lizarralde, Apaolaza, \& Mediavilla, 2019b), which describes the case of production plant of a company dedicated to producing steel tubes by extrusion; (2) a detailed discussion on how to exploit the bottleneck aligned with the practice-based view, which recognised that practices could provide superior performance to organisations; and (3) an overarching systematic process that enables an operative deployment in the specific steps to select strategically the bottleneck and exploit this constraint according to some of Goldratt's seminal proposals.

Keywords: drum-buffer-rope, theory of constraints, make-to-order, strategic decision

\section{To cite this article:}

Lizarralde-Aiastui, A., Apaolaza-Perez de Eulate, U., \& Mediavilla-Guisasola, M. (2020). A Strategic Approach for Bottleneck Identification in Make-To-Order Environments: A Drum-Buffer-Rope Action Research Based Case Study. Journal of Industrial Engineering and Management, 13(1), 18-37. https://doi.org/10.3926/jiem.2868 


\section{Introduction}

Make-to-order (MTO) companies are increasingly sensitized with concepts from other industries, such as flexibility, quality and the ability to adapt to consumer demand (Sultana \& Ahmed, 2014). Customers demand more variety and more reliable products, as well as shorter delivery times (Romagnoli, 2015; Borreguero-Sanchidrian, Pulido, Garcia-Sanchez \& Ortega-Mier, 2018). Therefore, the managers of MTO organisations are pressured to reduce inventory levels and achieve maximum use of their resources.

Two types of manufacturing scenarios exist in MTO environments: repeat business customizers (RBC) and versatile manufacturing companies (VMC) (Amaro, Hendry \& Kingsman, 1999). VMC are usually organised in job shops and have high management capabilities due to the typology of material flow (Stevenson, Hendry \& Kingsman, 2005). Additionally, if the MTO environment produces many final products from few raw materialsknown as a "V plant" (Lockamy, 2013)—the problem of achieving high machine utilisation and good service levels is heightened (Darlington, Francis, Found \& Thomas, 2015).

Therefore, production planning and control systems (PPCS) are crucial tools for meeting increasingly high customer demands and expectations in MTO scenarios (Manikas, Gupta \& Boyd, 2015). Typical functions of a PPCS include planning material requirements, demand management, capacity and the scheduling and sequencing of jobs. The main purpose of these functions is reducing the work in progress, minimizing lead times, improving responsiveness to demand changes and improving the delivery date adherence (Stevenson et al., 2005). Consequently, PPCS have become a crucial element for achieving maximum efficiency in MTO-VMC plants (Stevenson et al., 2005; Olhager \& Rudberg, 2002; Gaury, Kleijnen \& Pierreval, 2001) and have a notable impact on aspects such as work-in-progress (WIP), cycle times and on-time delivery (Maccarthy \& Fernandes, 2000). Since these are important objectives, choosing the right PPCS is a crucial, strategic decision.

Given the lack of empirical research from practical MTO-VMC contexts regarding the suitability of different PPCS, the researchers started a challenging research project oriented to provide new knowledge and practical contributions to this field. One of the first academic outcomes of the research project has been an action research based paper of a company dedicated to producing steel tubes by extrusion (Lizarralde, Apaolaza, \& Mediavilla, 2019b). This work included a first version of a strategic-oriented systematic process for DBR application. However, the findings were limited to a single case, so the development of additional cases in MTO contexts with different organizations could deepen understanding of the underlying factors, strengthening the validity of the proposed process.

This paper contributes to the ongoing discussion by exposing the implementation process of drum-buffer-rope (DBR) - the PPCS within the theory of constraints (TOC) - in a high-value, MTO-VMC machined and welded solutions manufacturing company. The few existing studies based on simulation suggest a superior performance of DBR in MTO-VMC contexts compared to other PPCS.

Therefore, the authors proposed a systematic process for deploying the first two steps of the TOC within a PPCS, especially in the selection and exploitation of the production system constraint through integrating a strategic perspective. The systemic process was based on the seminal work from Goldratt's TOC (Goldratt \& Cox, 2003) and included key aspects from theories on strategy, such as the resource-based view (RBV) and practice-based view (PBV). The RBV and PBV argue the importance of resources and practices in achieving competitive advantage and/or improved firm performance.

The literature review on PPCS is presented first, followed by the research methodology. An adaptation of the TOC-DBR is then suggested for bottleneck selection by proposing a systematic decision-making process; this adaptation is presented by means of a case study in which the researchers took active part. Finally, the practical results and academic implications are presented and discussed to gain insight and to suggest areas for further research.

\section{Literature Review}

Since the mid-twentieth century, various PPCS have been introduced. For example, material requirement planning (MRP) systems focus their efforts on detailed production schedules and may be more suitable for make-to-stock 
environments (Stevenson et al., 2005). MRP systems attempt to minimize the costs associated with the entire planning cycle. Other systems prioritize the improvement of the flow of materials (i.e., the speed at which raw material is transformed into finished product) and the systematic reduction of waste (i.e., everything that does not add value to the process) (Deming, 1982; Ohno, 1988; Womack, Jones \& Roos, 2008). Some of these systems include the Kanban (Berkley, 1992) and the Constant WIP (CONWIP) (Spearman \& Zazanis, 1992) and are usually suitable for large volumes and little production variety.

Regardless of the system, the literature studying PPCS lacks sufficient evidence about how these systems should be applied in discrete production environments (usually MTO) (Maylor, Turner \& Murray-Webster, 2015) and about which of the systems have been more adequate in practice. For environments with a high variety of products and low volume of production (characteristics of MTO-VMC companies), the successful application of systems such as MRP, Kanban or CONWIP has proven difficult (Darlington et al., 2015; Guan, Peng, Ma, Zhang \& Li, 2008). However, empirical evidence of the application of other PPCS — such as DBR (Goldratt \& Cox, 2005), quick response-manufacturing (Suri, 1998) and agile manufacturing (Christopher \& Towill, 2000)—is lacking for this type of scenario.

The TOC (Goldratt \& Fox, 1986; Goldratt \& Cox, 2005; Goldratt, 1990) was presented in the 1980s and has great theoretical and practical dissemination in the industry. Mabin and Balderstone (2003) documented numerous implementations of TOC-DBR, noting that $80 \%$ of the companies utilising this system obtained improvements in meeting delivery deadlines and compliance. The main concept of the TOC is that every system has at least one constraint that limits its performance (Goldratt \& Cox, 2003). One of the TOC's strengths is focusing on this constraint as a basis for managing and improving the system. According to Goldratt and Cox (2003), a constraint, or bottleneck, is anything that limits a system from achieving higher performance. Therefore, identifying the bottleneck(s) and managing the organisation according to the impact of said bottleneck(s) are critical; an improvement of the bottleneck performance results in an improvement of the entire system.

The capacity of non-constrained resources is composed of both productive and idle capacity (Lockamy \& Cox, 1995). From a TOC perspective, idle capacity is not considered an excess of capacity but rather a margin of capacity that protects the system against uncertainty. The use of this idle capacity as productive capacity not only fails to improve throughput but also unnecessarily increases inventory.

The guide for implementing TOC principles in companies is known as the process of on-going improvement and is composed of the two following prerequisites: (1) defining the system and identifying its goal and (2) defining the measures to align the system with its purpose. The process of on-going improvement also includes five focusing steps (Rahman, 1998; Watson, Blackstone \& Gardiner, 2007) in which DBR is limited to steps 1 to 3 (Figure 1).

\subsection{Production Planning and Control System of the Theory of Constraints}

The PPCS of the TOC is DBR, which has attracted a lot of attention from academia (Mabin \& Balderstone, 2003). This is a powerful technique used in companies with bottleneck(s) (also called the drum) that is oriented toward addressing market or physical constraints (Thürer, Stevenson, Silva \& Qu, 2017). The key strength of this approach is its simplicity; to control the whole system, precision is required only in the bottleneck (Gupta \& Snyder, 2009). The bottleneck is the resource that limits the total capacity of the system (Goldratt, 1990) and therefore has vital influence on the company's achievement of its business objectives. Physical constraints must be exploited (i.e., managed as effectively as possible in terms of the goal), whereas managerial constraints must be eliminated and replaced by a policy aligned with the goal (Rahman, 1998).

Once the constraint has been identified, DBR synchronizes production with customer requirements through the rope (i.e., the connection between the input of work and the bottleneck) (Thürer et al., 2017). Finally, DBR uses the drum, or bottleneck, and shipping buffers ("time or a time-equivalent amount of WIP") to enable this synchronisation while protecting the throughput of the system from variability and reduced levels of WIP (Thürer et al., 2017). Usually, the rest of the resources do not need to be programmed, since each operation is governed based on the buffer consumption of each order and provides great simplicity to the PPCS (Goldratt, 1990). 


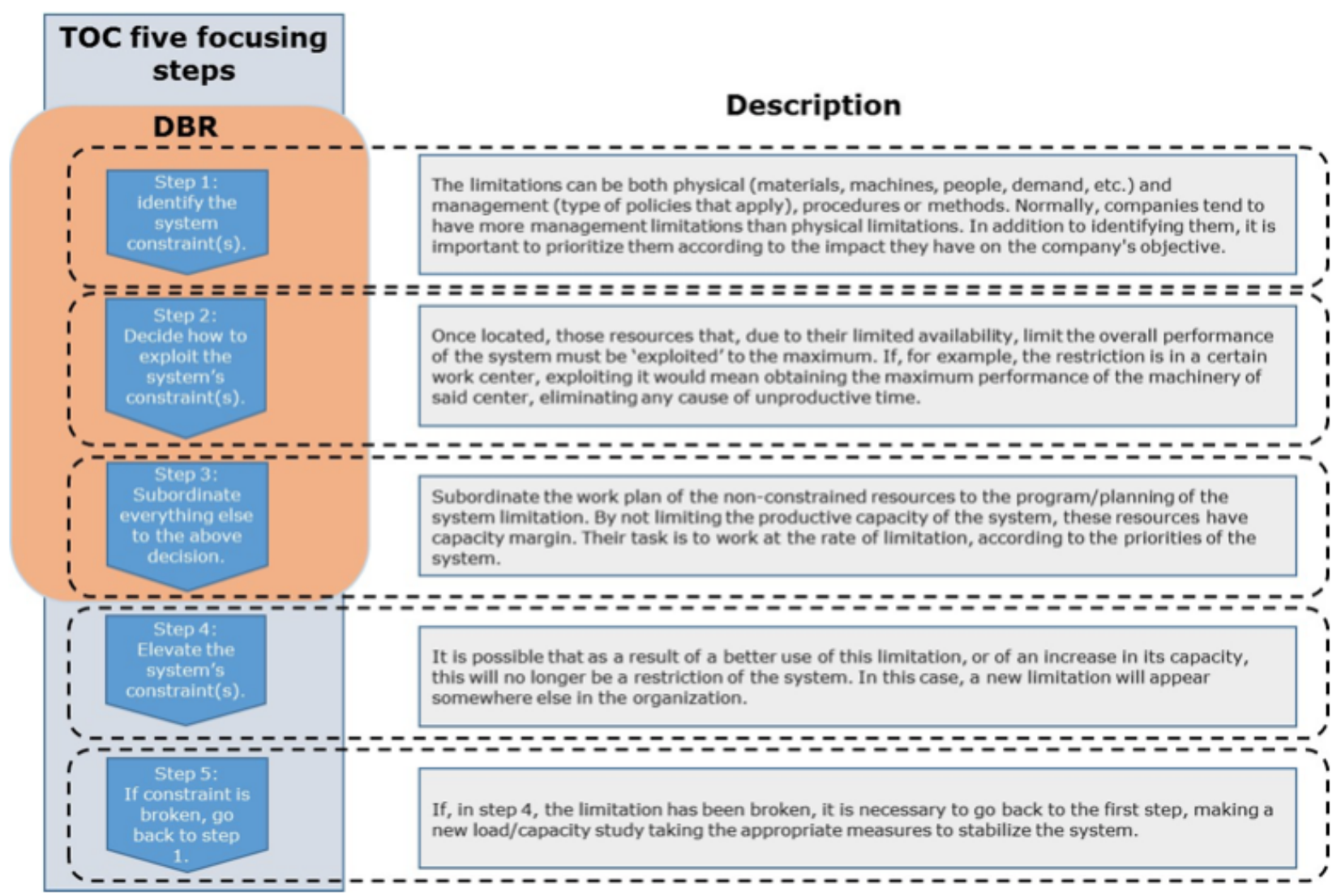

Figure 1. Five focusing steps of the TOC and DBR limited to first three steps (Lizarralde et al., 2019b)

The benefits of applying DBR have been documented in the literature (Panizzolo, 2016; Watson et al., 2007), confirming significant results in terms of inventory, WIP and lead time reduction as well as delivery performance improvement. However, most of the research related to the effectiveness of DBR focuses on simulations under specific conditions.

Although the documented results regarding the successful implementation of the TOC and DBR are mainly related to repetitive manufacturing, some promising cases have been related to MTO contexts (Stevenson et al., 2005). However, despite the existence of an extensive bibliography discussing the use of the TOC, real-world research related to current job shop contexts is lacking. The effectiveness of a TOC PPCS for manufacturing systems with customised products (which usually present difficulties estimating the times of processes in their routes in advance) has been checked analytically in the literature (Gupta \& Snyder, 2009). Nevertheless, no empirical studies in the industry have facilitated the understanding of how to implement this system. Rabbani and Tanhaie (2015) stated that, due to the complexity of job shops management, little attention has been paid to this type of scenario in the literature. In addition, studies of the implications of the first two steps of the TOC-DBR in real productive systems are lacking (Gupta \& Boyd, 2008); approaches have only been based on simulations and on the load versus capacity analysis of the system. Moreover, some authors have claimed that new methods are needed to determine the system's restriction (Naor, Bernardes \& Coman, 2013). Thus, further research has been encouraged to validate the presented findings, with special interest in the study of additional, current complex cases including many products (Thürer et al., 2017).

Therefore, the objective of this research was to develop a systematic decision-making process by means of TOC-DBR to identify and exploit the bottleneck of a productive system in MTO-VMC environments. The research question was as follows: How can the constraint of a production system in the MTO-VMC context be systematically—and by means of TOC-DBR—selected and exploited, in order to enhance competitive advantage/firm performance? 


\section{Research Methodology}

The practical nature of the research project made action research (AR) an appropriate methodological approach, since AR aims to contribute to academic research while solving practical, real-life problems. Additionally, AR requires that researchers be actively involved in the change process (Coughlan \& Coghlan, 2002; Eden \& Huxham, 1996; Susman \& Evered, 1978). AR is a variant of case study research, a method frequently used in operations management research to describe and explore an area without a previously proposed theory (Handfield \& Melnyk, 1998). This type of research has already been highlighted in the review of the relevant literature.

In AR, the planning-action-observation-evaluation cycle occurs several times (Coughlan \& Coghlan, 2002; Susman \& Evered, 1978), and its result is both action and research (Coughlan \& Coghlan, 2002). This is unlike the traditional positivist research approaches that aim only at generating new knowledge. The ongoing researchreflection process that characterizes AR means that learning is gained in action; since operations management research often requires learning from the application, AR has become a widely used approach for this discipline (Coughlan \& Coghlan, 2002; Susman \& Evered, 1978). According to Coughlan and Coghlan (2002), theory arises when applying AR and emerges through the development of a series of events as the problem is faced and the members of the organisation try to solve it with the help of the researcher.

Coughlan \& Coghlan (2002) proposed a detailed process of action research by defining an eight-steps-cycle (Figure 2) that authors will take as a reference model for enacting action research in this research.

The detailed content of the eight steps of Coughlan \& Coghlan (2002), is summarized in the Table 1.

The research project had the aim to respond to academic as well as to managerial challenges, which enabled to design empirically based research program (Figure 3). Action Research (AR) has been used as the principal empirical research strategy in construction of systematic process, test of systematic process and validity/academic contribution phases of the research program.

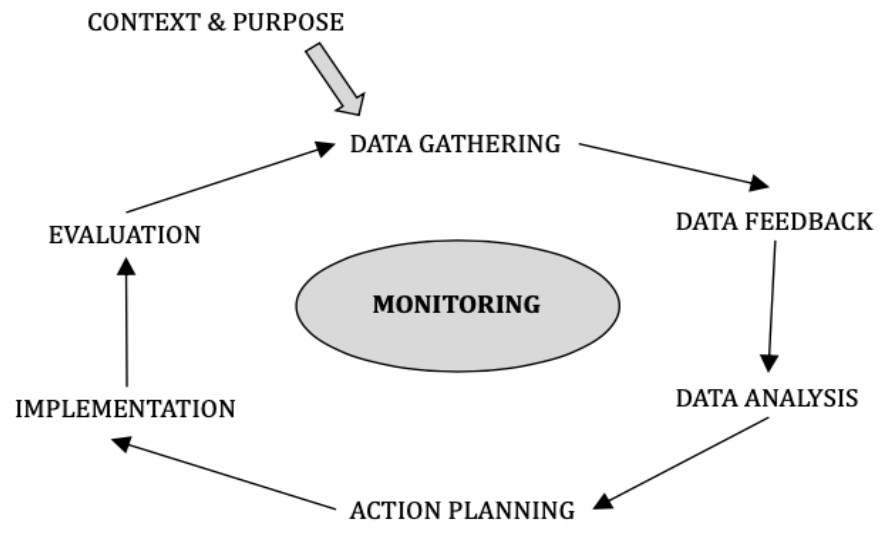

Figure 2. Action research cycle (Coughlan \& Coghlan, 2002)

\begin{tabular}{|l|l|}
\hline \multicolumn{1}{|c|}{ Step } & \multicolumn{1}{c|}{ Content } \\
\hline $\begin{array}{l}\text { Context \& } \\
\text { Purpose }\end{array}$ & $\begin{array}{l}\text { That pre-step contains aspects regarding the rationale for action and for research. The rationale for action } \\
\text { means to assess the need for that project and what are the different forces driving for action. The rationale for } \\
\text { research is to identify why the project has theoretical interest, appropriateness of action research and the } \\
\text { expected contribution to knowledge. }\end{array}$ \\
\hline $\begin{array}{l}\text { Data } \\
\text { gathering }\end{array}$ & $\begin{array}{l}\text { That step means to gather "hard" and "soft" data through active involvement in the day-to-day processes } \\
\text { (formal and informally) related to the action research project. In words of Coughlan and Coghlan (Coughlan } \\
\text { \& Coghlan, 2002), "data are generated through participation in and observation of teams at work, problems } \\
\text { being solved, decisions being made and so on, but also through the interventions which are made to advance } \\
\text { the project [...]So, the action researcher is dealing with directly observable phenomena in the organisations } \\
\text { with which they are working [...] Here, the critical issue is that of how to be helpful to the client system and, at } \\
\text { the same time, how to inquire in what is being observed". }\end{array}$ \\
\hline
\end{tabular}




\begin{tabular}{|l|l|}
\hline \multicolumn{1}{|c|}{ Step } & \multicolumn{1}{c|}{ Content } \\
\hline $\begin{array}{l}\text { Data } \\
\text { feedback }\end{array}$ & The researcher feeds the case company regarding the gathered data before going on further analysis. \\
\hline $\begin{array}{l}\text { Data } \\
\text { analysis }\end{array}$ & $\begin{array}{l}\text { The data analysis is a joint exercise of researchers and the involved practitioners (e.g. management team in our } \\
\text { industrial cases). An interesting observation from Coughlan and Coghlan (Coughlan \& Coghlan, 2002) is that } \\
\text { this analysis is done on the basis that "clients know their organisation best, know what will work and, } \\
\text { ultimately, will be the ones to implement and follow through on whatever actions will be taken. Hence, their } \\
\text { involvement in the analysis is critical". }\end{array}$ \\
\hline $\begin{array}{l}\text { Action } \\
\text { planning }\end{array}$ & $\begin{array}{l}\text { The analysis lead to the action step, which is a joint exercise too for the same reason and the data analysis. } \\
\text { Senior Researcher and the company top management set who does what and when. } \\
\text { Key questions are regarding what needs to change, in what part of the organisation, type of change, necessary } \\
\text { support and how to create commitment and minimise resistance to change. }\end{array}$ \\
\hline $\begin{array}{l}\text { Implement } \\
\text { ation }\end{array}$ & $\begin{array}{l}\text { The case company is the responsible for the planned action, which means to make the wished changes and } \\
\text { follow the plans. } \\
\text { The client implements the planned action. This involves making the desired changes and following through in } \\
\text { the plans in collaboration with relevant key members of the organisation. }\end{array}$ \\
\hline Evaluation & $\begin{array}{l}\text { This step contains the reflection regarding the action, the review of the process to serve as an input in the next } \\
\text { cycle of planning \& action. The evaluation is a crucial aspect for the necessary learning of action research, } \\
\text { since it avoids that the actions continue, and errors are minimised. }\end{array}$ \\
\hline Monitoring & $\begin{array}{l}\text { That is a meta-step occurring along all cycles, continually monitoring each of the six main steps, inquiring in } \\
\text { what is taking place, how these steps are being conducted, and what underlying assumptions are operative }\end{array}$ \\
\hline
\end{tabular}

Table 1. Content of eight steps based action research process (Coughlan \& Coghlan, 2002)

\begin{tabular}{|c|c|c|c|c|}
\hline Case & MTO type & Company sector & Related papers & Key contribution \\
\hline Case 1 & $\mathrm{RBC}$ & $\begin{array}{l}\text { Wind-energy } \\
\text { towers } \\
\text { manufacturer }\end{array}$ & $\begin{array}{l}\text { Paper in XXI International } \\
\text { Congress on Project } \\
\text { Management and Engineering } \\
\text { (Lizarralde \& Apaolaza, } \\
\text { 2017) Cádiz, Spain }\end{array}$ & DBR implementation in MTO scenario \\
\hline Case 2 & $\mathrm{RBC}$ & $\begin{array}{l}\text { Aeronautical } \\
\text { sector precision } \\
\text { machining }\end{array}$ & $\begin{array}{c}\text { Published on Dirección y } \\
\text { Organización (Lizarralde, } \\
\text { Apaolaza, \& Mediavilla, 2019a) }\end{array}$ & $\begin{array}{l}\text { DBR implementation process with some new } \\
\text { sub/steps }\end{array}$ \\
\hline Case 3 & VMC & $\begin{array}{l}\text { Steel tubes } \\
\text { manufacturer } \\
\text { through hot } \\
\text { extrusion process }\end{array}$ & $\begin{array}{l}\text { Published on DYNA } \\
\text { (Lizarralde et al., 2019b) }\end{array}$ & $\begin{array}{l}\text { Specific four criteria to select the bottleneck } \\
\text { providing a strategic perspective inspired by } \\
\text { the main concepts from the RBV theory }\end{array}$ \\
\hline Case 4 & VMC & $\begin{array}{c}\text { Machined and } \\
\text { welded solutions }\end{array}$ & Current paper & $\begin{array}{l}\text { Detailed discussion on how to exploit the } \\
\text { bottleneck, which was aligned with the } \\
\text { Practice Based View theory and how the } \\
\text { systematic process containing the four criteria } \\
\text { to select the bottleneck should be operatively } \\
\text { applied }\end{array}$ \\
\hline $\begin{array}{l}\text { Cross } \\
\text { case } \\
\text { study }\end{array}$ & $\begin{array}{l}2 \mathrm{RBC} \\
2 \mathrm{VMC}\end{array}$ & $\begin{array}{l}\text { Predecessor } 4 \text { case } \\
\text { studies }\end{array}$ & Future research & Conclusion of the research project \\
\hline
\end{tabular}

Table 2. Research program cases and related publications

Table 2 shows the cases included in the research program and the related publications in selected international congresses and journals.

The purpose of this research was to discover, in detail, the process of implementing DBR in the production plant of a company dedicated to high-precision machining and high-value machined and welded solutions. The company 
had faced difficulties maintaining its high service level for its customers and had high WIP. The fieldwork carried out by the researchers was developed between January and June 2018.

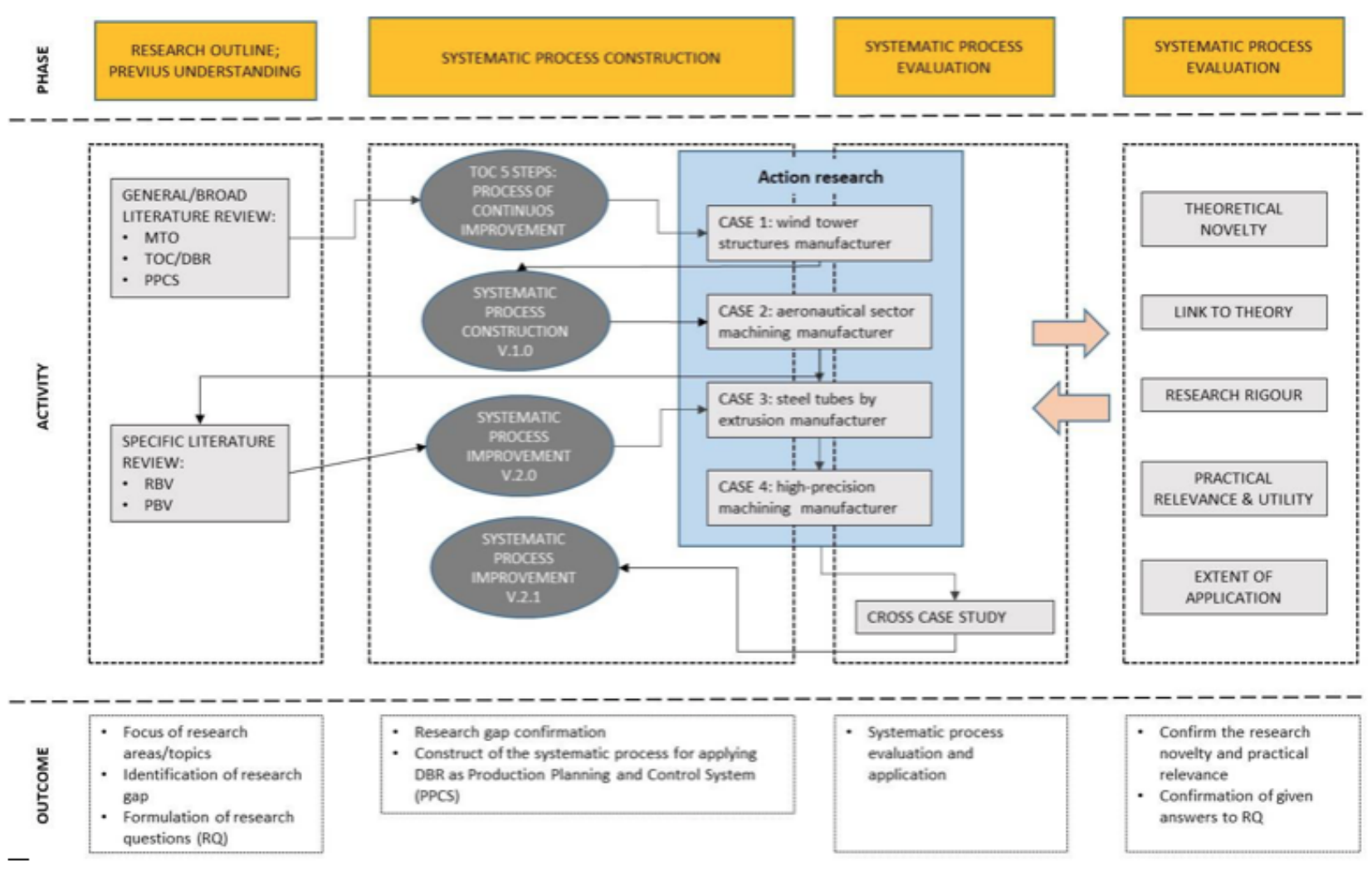

Figure 3. Research project program

\section{Field Work: Applying the Model to the Case Company}

The case company was a market leader in high-precision machining located in the Basque Country (Spain). This company specialised in providing customised solutions for its customers worldwide (e.g., complex structures, pressure vessels or vacuum chambers). Its manufacturing assets included many different technologies, such as cutting, press forming, welding, blasting, pickling and passivating, shot-blasting, painting and machining. The researchers considered this case a valuable study for academics and practitioners, since it represented a genuine, fully MTO company with a job shop layout and a variety of products and resource needs entailing a complex context.

The case company was comprised of 90 highly qualified workers who combined their long years of experience with wide-ranging know-how to make use of the latest process engineering tools. Mastering the production processes had been a crucial aspect of the company's long-term strategy. Other key strategic decisions of the company were as follows:

- Orientation toward niche markets that were demanding from a technical and organisational point of view.

- Diversification in markets, both geographically and by sectors.

- Integration in the customer's value chain, providing solutions beyond manufacturing, such as know-how in mechanically welded solutions and materials advice.

- On-time delivery orientation, a critical condition to gain customers' trust.

The company had a comfortable solution as niche players, but the top management was aware that more profound problems existed. During interviews with the management team, problems meeting on-time delivery expectations were mentioned, but the management team considered the existing capacity great enough to complete the work according to customer due dates. However, top management knew that overtime and outsourcing were intensively used. This meant 
that their orders were delayed, and the WIP was considered excessive. Additionally, the effort necessary to plan, program and track the manufacturing was enormous. Therefore, the company contacted the researchers to help increase their reliability in deliveries and reduce their delivery times by applying a new PPCS system.

\subsection{Drum-Buffer-Rope Implementation Process}

Since the case was an MTO-VMC company, the researchers determined that the change to a PPCS based on TOC-DBR could be the most appropriate (Stevenson et al., 2005). Specifically, the case study focused on integrating a strategic perspective for the selection and exploitation of the bottleneck by implementing the systematic process developed by the researchers (Figure 2) in response the research question.

Anyhow, the research project covered the five steps defined for implementing TOC principles, but this article has been limited in its focus to the following two steps — shown as defined by Goldratt—:

1. Identify the system's limitations. These limitations could be both physical (materials, machines, people, level of demand, etc.) and managerial. Normally, companies have physical limitations, but they usually have even more managerial limitations, like the types of policies, procedures and methods that they apply. Since the system's constraint determines the company's performance, maximum system performance can only be achieved by identifying the company constraint. Identifying the constraint is, therefore, the necessary first step (Goldratt \& Cox, 2003).

2. Decide how to exploit the limitations of the system. Once located, those resources that, due to their limited availability, limit the overall system performance should be exploited to make optimal use of the imposed limitation. The constraint's capacity is scarce. Therefore, it must not be wasted but rather be fully utilised. This step defines the management rules for the constraint only. By implication, this step can only be used when dealing with physical constraints, a problem which will be overcome with the proposed decision-making guidelines within the five focusing steps (Goldratt \& Cox, 2003).

The researchers developed a systematic process of four steps (Figure 4) for the implementation of the first two steps of TOC-DBR in MTO-VMC production systems. This process was derived from the seminal work of Goldratt (Goldratt \& Cox, 2003), introduced key insights from RBV and PBV strategic perspectives and included original contributions from the authors for understanding what purpose should be fulfilled, what decisions should be made and how the four steps should be applied.
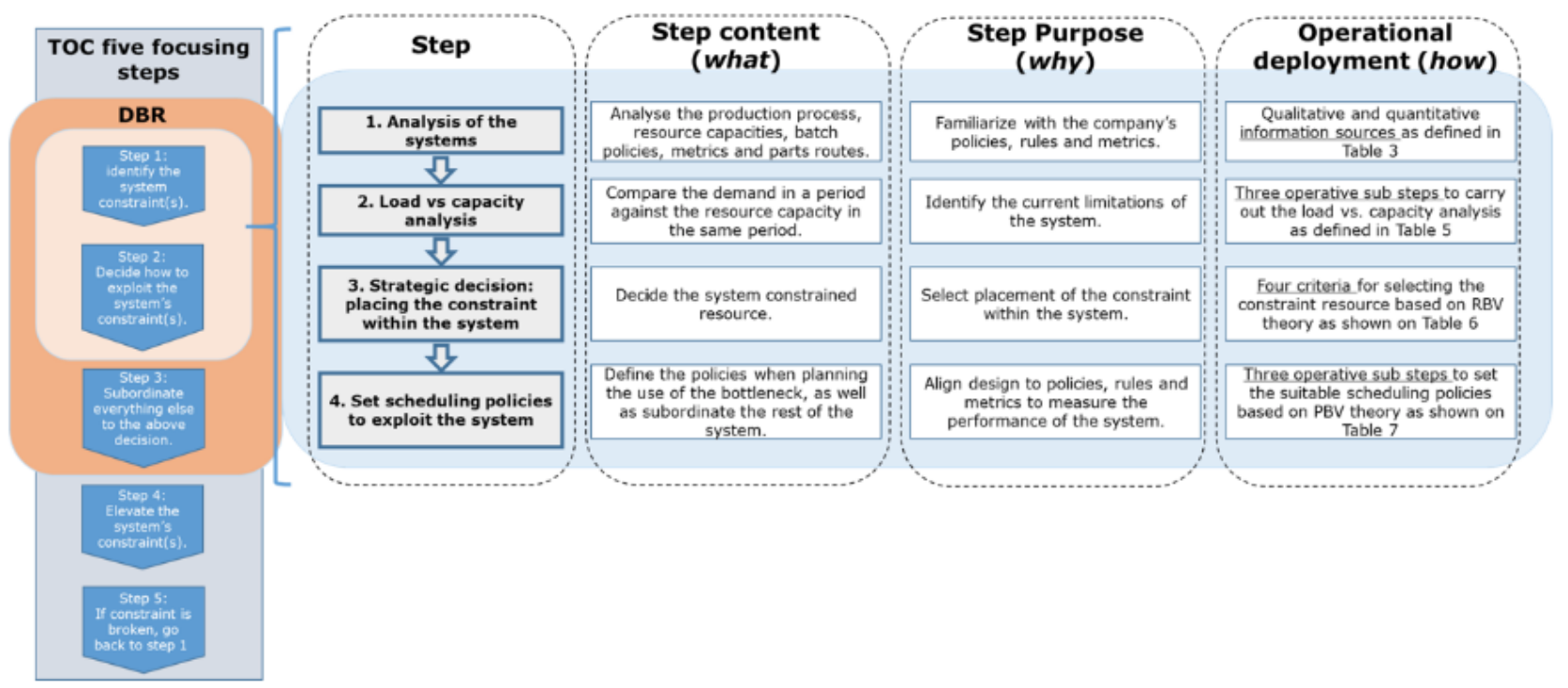

Figure 4. Systematic process for TOC steps 1 and 2: Process steps, step content, step purpose and operational deployment. Based and extended of (Lizarralde et al., 2019b) 
The systematic process developed by authors is utilised along the action research process carried out in that particular industrial case. In fact, Figure 5 shows how are put in practice the steps from our systematic process in the planning-action-observation-evaluation cycle. Denote that, e.g. the steps $1 \& 2$ is enacted on two cycles in the data-related first three stages while steps $3 \& 4$ have also more than one cycle along the action planning, implementation and evaluation.

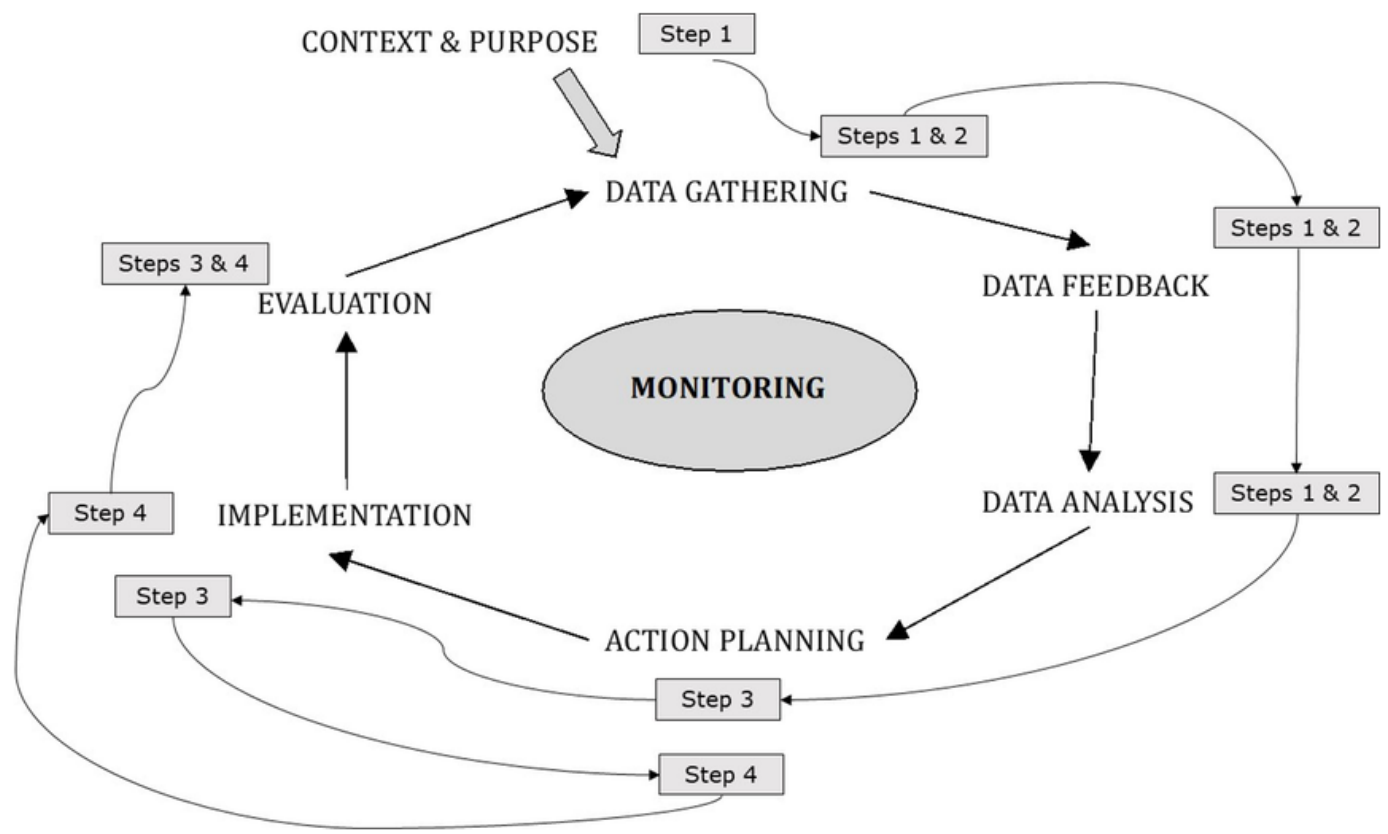

Figure 5. Action research cycle steps (Coughlan \& Coghlan, 2002) and link to systematic process developed by authors

\subsubsection{Step 1: Analysis of the System}

The first step of the systematic process aimed at gaining a profound understanding of the current situation in the PPCS, especially of the manufacturing process and policies, resource capacities and performance metrics based on the information acquired from source, is shown in Table 3.

\begin{tabular}{|l|c|c|c|c|}
\hline \multirow{2}{*}{\multicolumn{1}{c|}{$\begin{array}{c}\text { Needed } \\
\text { information }\end{array}$}} & $\begin{array}{c}\text { Enterprise Resource } \\
\text { Planning (ERP) }\end{array}$ & $\begin{array}{c}\text { Semi-structured } \\
\text { interviews with } \\
\text { managers }\end{array}$ & $\begin{array}{c}\text { Direct observation in } \\
\text { planning and } \\
\text { programming process }\end{array}$ & $\begin{array}{c}\text { Key performance } \\
\text { indicator board }\end{array}$ \\
\hline Manufacturing routes & $\bullet$ & $\bullet$ & & \\
\hline Resources capacity & $\bullet$ & $\bullet$ & & \\
\hline Productive process & & $\bullet$ & & \\
\hline Plant type (V, A, T) & & $\bullet$ & & \\
\hline Batch policy & & $\bullet$ & & \\
\hline Metrics & & & & \\
\hline
\end{tabular}

Table 3. Information sources for step 1

The analysis of the current system was developed based on the key performance indicator board of the company, direct access to ERP data, semi-structured interviews with managers and direct observation of the planning and programming process (see Table 4 for a summary). 
The system analysis confirmed that the current planning process was focused on maximising the performance and output of all sections. Thus, the sections developed their local weekly production plans based on production orders but were oriented toward the "hours per day" output index (a performance metric of the section that meant all productive hours worked per day; the goal was to maximise this ratio).

KPI-related observations

- Low on-time delivery rate (objective: $80 \%$; achieved: $50-70 \%$ )

- Average delivery time (objective: 6 weeks; achieved: 7-8 weeks)

- Delivery time: key to success

\section{Process-related observations}

- Delays often occur at initial stages

- Lack of visibility: load vs. capacity, priorities and overall perspective

- No planning/programming tool

- Lack of organisational capabilities

- Lack of qualification (need for training/learning)

Table 4. Synthesis of the initial situation

The effect of this approach was that the planning process launched the production orders as soon as possible to support the optimisation of hours worked in the section. For example, to maximise the hours worked each day, workers collected pieces of different deliverables in the first operation of the route to gain productivity. As a result, they manufactured orders from different dates' sales at the same time, thus producing excess WIP.

The level of WIP caused multiple problems in the case company, as follows:

- Controlling the WIP was difficult.

- Lead times exceeded the standards.

- On-time delivery was below the required rate. This was consistent with the literature, which showed that high resource usage rates and high on-time delivery levels were difficult to achieve in this kind of environment (Darlington et al., 2015).

\subsubsection{Step 2: Load Versus Capacity Analysis}

The second step of the systematic process intended to identify the current limitations of the system. For that purpose, capacity and workload were compared over a defined period (see Table 5 for the generic approach).

The research team decided to analyse the workload of the following five months, since this period included the pending portfolio of orders at that time. A team formed by the company's planning team and the researchers carried out a comparative analysis of the corresponding load versus the installed capacity in the different centres of the organisation.

The wide diversity of products and options made determining the actual load versus capacity difficulty, since process times were difficult to estimate accurately. In the analysis, the machining area was found to be the constraint. This area had the highest average use; on average, $99 \%$ of production drew on this resource. Anyhow, the difficulty to estimate process time made that occasionally additional capacity problems in other production areas upstream from the bottleneck could happen.

\begin{tabular}{|c|l|l|}
\hline Sub-step & \multicolumn{1}{|c|}{ Content } & \multicolumn{1}{|c|}{ Output } \\
\hline $2 \mathrm{a}$ & $\begin{array}{l}\text { Create a schedule horizon in the order book. Then calculate the } \\
\text { workload per production resource in the given period. }\end{array}$ & Workload per production resource \\
\hline $2 \mathrm{~b}$ & $\begin{array}{l}\text { Calculate capacity per production resource in the horizon set in sub- } \\
\text { step 2a. }\end{array}$ & Capacity per production resource \\
\hline $2 \mathrm{c}$ & $\begin{array}{l}\text { Compare each resource load vs. capacity as estimated in previous two } \\
\text { sub-steps. }\end{array}$ & Load/capacity analysis per resource \\
\hline $2 \mathrm{~d}$ & \begin{tabular}{l} 
Identify the most loaded resource during the period observed. \\
\hline
\end{tabular}
\end{tabular}

Table 5. Load versus capacity sub-steps 


\subsubsection{Step 3: Strategic Decision. Placing the Constraint within the System}

The output of step 3 of the systematic process was a decision concerning the constraint of the productive system (i.e., the bottleneck). As stated, the bottleneck of a manufacturing company determines its theoretical production capacity, or the maximum output ideally deliverable to the market. Many authors have recommended that the selection of the bottleneck should be done from a global and strategic perspective and that this selection is the responsibility of the company's top management (Cox, Blackstone \& Schleier, 2003; Goldratt, 1990; Pretorius, 2014; Ronen \& Pass, 2008). To be consistent with their strategic perspective, companies should decide what limits their capacity, carefully select this limitation and dimension the resource selected accordingly. Indeed, the RBV states that strategic resources contribute to the sustainability of the competitive advantage of the company. Furthermore, the conceptual framework Value-Rarity-Imitability-Organisation (VRIO), developed by Barney (1991), affirms that strategic resources are those that are valuable from the perspective of the organisation, are scarce and are difficult to imitate and are those that require organisational support for their exploitation.

Other authors have agreed that critical resources within a company must be treated in a special way (Dumond \& Dumond, 1993; Mathur, Jugdev \& Shing Fung, 2007). The approach suggested here consistently integrated DBR with these perspectives. Given its impact on overall performance of the system, the bottleneck was considered the strategic resource of the company that must be managed differently, requiring the subordination of the rest of the system to its needs. To develop a systematic and operative way of deploying the selection of the bottleneck, the researchers developed a list of criteria to assure a strategic approach when making this decision. These criteria were derived from existing literature (e.g., RBV or TOC-DBR) and were enriched with field experience from the industry (Table 6).

\begin{tabular}{|c|l|}
\hline Criteria & \multicolumn{1}{|c|}{ Content } \\
\hline Criterion 1 & $\begin{array}{l}\text { The bottleneck resource is limited in capacity; it is difficult to increase the capacity of the selected resource, } \\
\text { which occurs either by large investment or by finding subcontracting alternatives in suppliers. }\end{array}$ \\
\hline Criterion 2 & The bottleneck resource is a strength in internal ability; it must be the main knowledge of the organisation. \\
\hline Criterion 3 & The load in the bottleneck remains stable before changes in the product mix. \\
\hline Criterion 4 & The drum resource is common to the vast majority of products. \\
\hline
\end{tabular}

Table 6. Criteria for selecting the bottleneck

For the case company, the lead researcher coordinated the different activities within this step 3, and the top management of the company (CEO, Engineering Manager and Operations Manager) actively participated. Semi-structured interviews, group discussion sessions and convergence sessions were conducted. These activities, among others, led to the decision that the machining area was the bottleneck of the system. The key reasons for this decision were as follows:

- Criterion 1: The investment required was high in comparison with other activities. Furthermore, the lead time for incorporating new machining installations (engineering-to-order) could take several years.

- Criterion 2: Machining was a significant added-value operation from the product perspective.

- Criteria 1 and 2: Machining required critical knowledge from the organisation, and development may take long periods. Machining was also considered difficult to acquire and reproduce by third parties.

- Criteria 3 and 4: The machining was a common resource for nearly 100\% of the products, and its load remained stable over time. Consequently, the percentage of the total workload tended to remain stable.

In the case study, the bottleneck identified in step 2 and the constraint strategically selected in step 3 was the same (i.e., machining). If that had not been the case (i.e., the desired bottleneck from a strategic perspective [step 3] was different than the bottleneck identified in the load versus capacity analysis [step 2]), the company would have 
needed to take the necessary actions to ensure that the strategic resource selected as bottleneck was the actual limitation of the system. Only then could the process proceed to step 4.

\subsubsection{Step 4: Establish Scheduling Policies to Exploit the System}

Step 4 of the systematic process aimed at defining the proper production plan by meeting on-time delivery expectations and maximising the use of the constraint, which in practice meant establishing the proper scheduling policies according to the PPCS. Table 7 defines the operative sub-steps regarding exploiting a bottleneck.

\begin{tabular}{|c|l|l|}
\hline Sub-step & \multicolumn{1}{|c|}{ What to do } & \multicolumn{1}{c|}{ How and why } \\
\hline $4 \mathrm{a}$ & Generate bottleneck schedule proposal. & Desired delivery date, consumption in bottleneck and current load. \\
\hline 4b & $\begin{array}{l}\text { Load vs. capacity analysis of the routes } \\
\text { before and after the bottleneck according } \\
\text { to scheduling of sub-step 4a. }\end{array}$ & $\begin{array}{l}\text { Detection of load peaks in non-bottleneck resources generated by } \\
\text { scheduling (type of product, quantity, period) that were not limiting } \\
\text { in a load/aggregate capacity analysis. }\end{array}$ \\
\hline $4 \mathrm{c}$ & $\begin{array}{l}\text { If sub-step 4b shows capacity problems, } \\
\text { go to sub-step 4a. }\end{array}$ & $\begin{array}{l}\text { Schedule re-planning and learning for future program creation } \\
\text { (eventually creation of planning criteria). }\end{array}$ \\
\hline
\end{tabular}

Table 7. Operative sub-steps to exploit the system

In the case study, executing sub-step $4 \mathrm{a}$ revealed that on-time delivery was a crucial strategic factor for the company's business and had to be considered when deciding how best to exploit the bottleneck. Thus, the scheduling of the bottleneck had to consider not only the workload required by the sales orders but also (and more importantly) their required delivery date.

Therefore, step 4 focused on properly using the bottleneck selected in step 3. In other words, the practice related to governing the bottleneck was a key aspect for sustaining the competitive advantage of on-time delivery. This appreciation was in agreement with the common critique of RBV from operations management researchers, who stated that many resources were, for the most part, neither inimitable nor rare, yet these resources resulted in varying levels of performance (Bromiley \& Rau, 2014).

As a complementary theoretical foundation to the dominant RBV, Bromiley and Rau (2014) proposed the PBV. The PBV aims to explain variations in firm performance based on imitable and transferable practices, where "practices" are "a defined activity or set of activities that a variety of firms might execute" (Bromiley \& Rau, 2014: page 1249). In the PBV, scholars can propose publicly available practices for firms to imitate to enhance performance. These practices vary in their ease of adoption or imitation. Therefore, PBV enabled the researchers of this present case to enrich the VRIO resource selection by introducing the necessity of a proper bottleneck production program (as defined in Table 6).

Another fundamental aspect was sub-step 4b, which considered possible load peaks created in other resources due to the schedule defined in the bottleneck (Gupta \& Boyd, 2008). In other words, these resources, although not limiting in aggregate capacity, may have caused specific problems complying with the scheduled work before or after the bottleneck operation if their workload contained peaks in, for example, product type, quantity per type and time horizon (see Figure 6). For example, in the case company, the operation before the bottleneck (assembly and welding) was not capable of processing two orders with a high workload simultaneously without affecting the machining plan. The solution to this problem was based on a bottleneck work-programming rule that respected the maximum processable quantities in the assembly and welding section. Figure 6 shows a simplified example showing sub-step 4b.

The example contained in Figure 6 was created with four orders (numerically from order 1 to order 4 ) that had the same target end-date on week 6 . Regarding production capacity in that example, the welding and assembly section had seven resource units per week, and machining had four resource units per week. 
Since machining was the bottleneck of the system, the load of each order in the bottleneck was identical in both options 1 and 2 (two resource units in two weeks), but the product type that had been scheduled differed. However, the workload of welding (i.e., the preceding operation) may have varied depending on the scheduled program in the bottleneck:

- In option 1, the workload in the welding and assembly section may have been up to five resource units for two weeks on orders 1 and 3 , and up to two resource units for two weeks on orders 2 and 4 . That schedule unbalanced the workload in the welding and assembly section (eight resource units necessary in weeks 1 and 2; five resource units necessary in weeks 3 and 4) so that it could not be fulfilled properly, as it exceeded the installed capacity of seven resource units per week. This is a simplified example of "peaks" generated by way of scheduling the bottleneck.

- In option 2, on the other hand, the workload in assembly and welding was balanced throughout the week. Although the same total workload occurred in both options 1 and 2 (14 resource units), the workload in option 2 was equally distributed in seven resource units throughout all weeks.

The real execution in the case company included a bottleneck work-programming rule that limited the maximum process quantities of the critical processes - in this case, the welding and assembly area.

Option 1

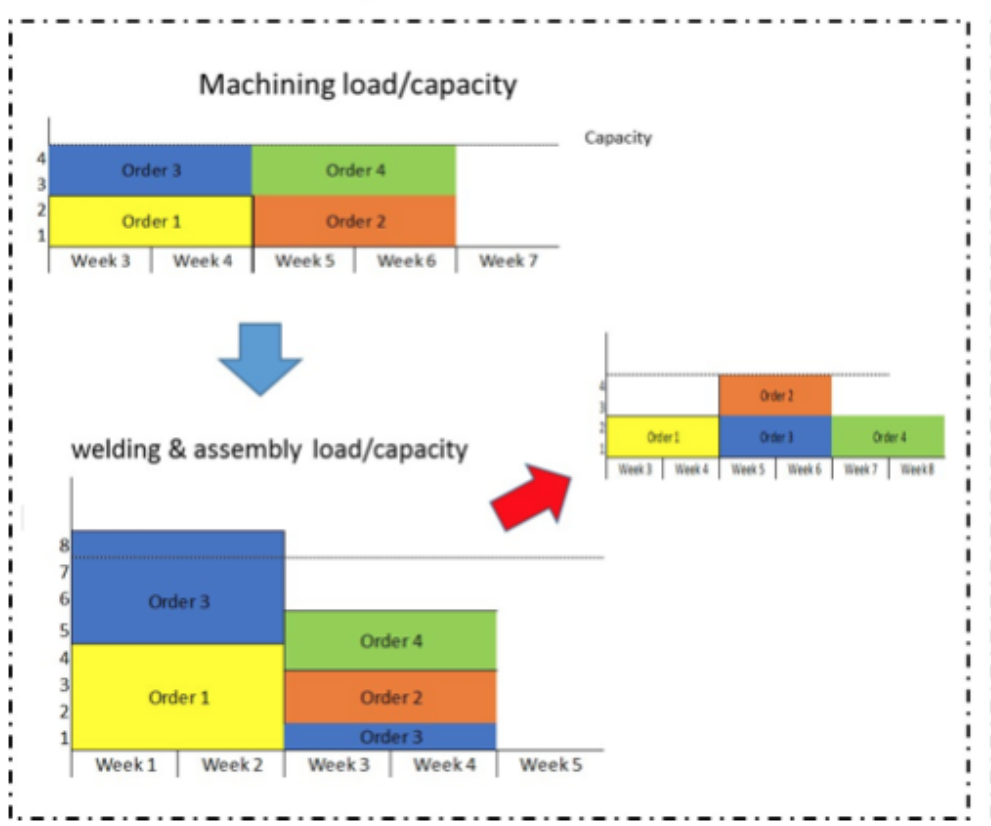

Option 2

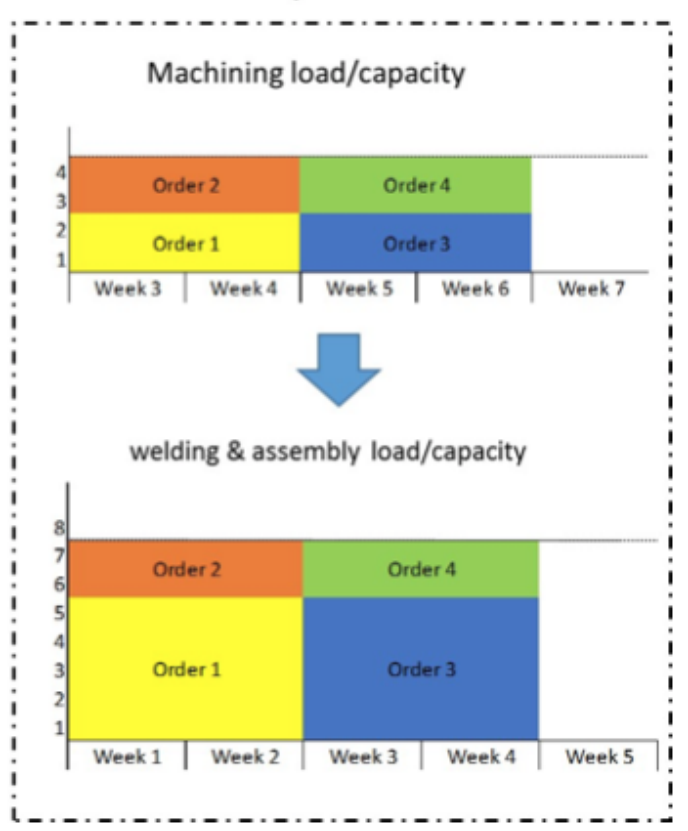

Figure 6. Illustrative example of the bottleneck exploitation based on the case study (real problem found during the action research project)

\section{Case Study Results}

\subsection{Practical Results}

The aim of this research was to examine the systemic utilisation of TOC-DBR as a PPCS for MTO-VMC contexts. Therefore, using the AR approach necessitated evaluating the fieldwork results from a practical perspective as well from the view of research process implementation and quality.

For the practical results of the case study, the implementation of the systematic process for selecting the bottleneck and exploiting it led to the following events and results (Table 8).

The application of TOC-DBR principles supposed a rupture versus the previous way of managing for the productive system. Although the main target remained the same (fulfilling customer orders on time in full), the 
focus before TOC-DBR implementation was to achieve the deployed local objectives in the different production areas (e.g., quantity of parts per day or hour in a given production area). This type of local objective was a potential source of organisational misalignment in the case company; decisions oriented toward improving resource efficiency often led to better results according to the local indicator.

However, this apparent improvement complicated the transitions between production areas, thereby obstructing the material flow along the entire manufacturing process. Productions sections were forced to react and change their production plans to obtain good results according to the objectives. The main consequence of the previous situation was a poor on-time delivery performance. Searching for local productivity improvements created workload peaks that were artificially induced, leading to unnecessary in-advance purchasing and subcontracting. In other words, the lack of aligned and coherent vision led to misaligned local decisions, causing a negative overall impact.

\begin{tabular}{|c|c|c|}
\hline $\begin{array}{l}\text { Supply chain } \\
\text { management } \\
\text { processes }\end{array}$ & Quantitative results & Qualitative results \\
\hline Plan & $\begin{array}{l}\text { Reduced time required for } \\
\text { planning and scheduling: 50\%. }\end{array}$ & $\begin{array}{l}\text { The way that manufacturing orders were launched was } \\
\text { completely changed. Only the bottleneck was scheduled by } \\
\text { means of production orders based on the required date of sales } \\
\text { orders. }\end{array}$ \\
\hline Source & $\begin{array}{l}\text { Reduced number of open } \\
\text { purchase orders: } 20 \% \text {. }\end{array}$ & $\begin{array}{l}\text { The purchase orders were released according to the required } \\
\text { delivery dates in the manufacturing process. Formerly, the } \\
\text { purchase orders were released as soon as possible, often sooner } \\
\text { than required, to keep production running. }\end{array}$ \\
\hline Make & $\begin{array}{l}\text { - Reduced lead time: } 10 \% \text {. } \\
\text { - Reduced WIP (number of } \\
\text { orders running simultaneously): } \\
20 \% \text {. } \\
\text { - Reduced the volume of semi- } \\
\text { finished material in progress: } \\
40 \% \text {. } \\
\text { - Reduced quality-related } \\
\text { incidents: } 20 \% \text {. } \\
\text { - Reduced subcontracted } \\
\text { operations. }\end{array}$ & $\begin{array}{l}\text { - The main immediate change on the shop floor was an } \\
\text { unprecedented production flow, caused by the reduction of WIP } \\
\text { levels. } \\
\text { - In spite of the production improvement achieved, the } \\
\text { perception from the production area was that there was less } \\
\text { work than before because there was a low amount of } \\
\text { semi-finished material waiting to be processed. } \\
\text { - As a result of the new production flow, certain capacity was } \\
\text { released, allowing more time for internal operations that had } \\
\text { previously been subcontracted. }\end{array}$ \\
\hline Deliver & $\begin{array}{l}\text { Service levels increased from } \\
50 \% \text { to } 70 \% \text {. }\end{array}$ & $\begin{array}{l}\text { - The trend as of June } 2017 \text { looked promising, as it was still } \\
\text { improving. } \\
\text { - The change allowed more robust decision-making in the sales } \\
\text { area. With the new system, the sales managers could easily assess } \\
\text { the feasibility of the Request-for-quotations (RFQs). }\end{array}$ \\
\hline
\end{tabular}

Table 8. Case study practical results

\subsection{Discussion on Action Research Process}

Action research-based works should also consider (together with the practical contribution to solve a real-world problem) the quality of the research process and if the necessary topics have been adequately covered. For example, the formal writing of an action research paper has been already discussed in the literature and there are specific topics that authors should cover (Coghlan \& Brannick, 2014; McNiff \& Whitehead, 2009): purpose and rational of the research (see chapter 1 for further details); context (see chapter 1 for further details); methodology and methods of inquiry (see chapter 3, 4 and 5 for further details); story and outcomes (see chapter 4 and 5 for further details); self-reflection and learning of the action researcher (see chapter 4 and 5 for further details); reflection on the story in the light of the experience and the theory (see chapter 5 and 6 for further details); extrapolation to a broader context and articulation of usable knowledge (see chapter 5 and 6 for further details). The authors of this paper did not create a specific 
subchapter for each of the topics, but we consider that all these relevant issues have been clearly answered along our work.

Precisely related to the action research sequence, the following Table 9 details that each of the eight steps for action research proposed by Coughlan and Coghlan (2002) (see Table 1) has been properly covered by the research process.

Finally, referring to the quality of the research process itself, the process was developed under a rigorous methodological approach, considering the following quality criteria (Table 10) required for adequate execution of AR (Coughlan \& Coghlan, 2002). This enabled the researchers to respond to the usual criticism of AR (Coughlan \& Coghlan, 2002), such as consultancy masked as research or research that lacks repetition and generalization due to its own contextual nature.

\begin{tabular}{|c|c|}
\hline Step & Content \\
\hline Context \& Purpose & $\begin{array}{l}\text { On the one hand, the justification of the action has been identified by clearly understanding the } \\
\text { problem that the company had in the process of planning and production management. On the } \\
\text { other hand, regarding the rationale for research: (1) the linkage to the theory and the related } \\
\text { research gaps was identified during the literature review of the research work; (2) the } \\
\text { appropriateness for action research was confirmed by the practical nature of the case; and, (3) the } \\
\text { contribution to the theory was also identified by means of the research question and additional } \\
\text { gaps to be answered. }\end{array}$ \\
\hline Data gathering & $\begin{array}{l}\text { The author of this paper was the main researcher of the industrial case and the gathered data from } \\
\text { many different sources (see Table 2). Some "hard" data were collected by analysing the Enterprise } \\
\text { Resource Planning (ERP) and Key performance indicator board. } \\
\text { The access and collection to "soft" data was possible through semi-structured interviews with } \\
\text { managers, direct observation in planning and programming process and, finally, informal } \\
\text { conversation with different executives of the case company. }\end{array}$ \\
\hline Data feedback & $\begin{array}{l}\text { The main research had regular feedback meetings with the case company dedicated team and the } \\
\text { General Manager in order to present the collected data and inquire for their reliability or potential } \\
\text { error or missing aspects. }\end{array}$ \\
\hline Data analysis & $\begin{array}{l}\text { The main researcher coordinated the group work with the case company team in order to discuss } \\
\text { and analyse the "hard" and "soft" data that were gathered along the process. } \\
\text { Especially steps } 1 \text { and } 2 \text { were phases of data collection while steps } 3 \text { and } 4 \text { were for analysis. With } \\
\text { all the data collected, decisions were made as detailed in the field work chapter }\end{array}$ \\
\hline Action planning & $\begin{array}{l}\text { Once the data was analysed, in step three it is necessary to decide which resource will be the } \\
\text { limitation of the system. In this phase, the steps to be taken to make this decision effective must be } \\
\text { planned. On the other hand, once the system constraint has been decided, in step } 4 \text { it is necessary } \\
\text { to decide how to operate the system and plan its implementation. }\end{array}$ \\
\hline Implementation & $\begin{array}{l}\text { The implementation is given in steps } 3 \text { and } 4 \text { of our systematic process. The case company } \\
\text { (supported onsite by the main researcher) executed the main actions that were defined in planning } \\
\text { step. }\end{array}$ \\
\hline Evaluation & $\begin{array}{l}\text { The evaluation has been done on practical results and research quality aspects. The research } \\
\text { practical results were evaluated by comparing the target set by the case company for the awarding } \\
\text { process. This target was met, and the project team found useful the experience of applying a new } \\
\text { PPCS based on DBR. Anyhow, the project team also admitted that the preparation work (data } \\
\text { gathering, data analysis and action planning) was hard and required a lot of effort. } \\
\text { Regarding the research quality, the action research process was confronted versus the criteria for } \\
\text { research quality defined and is shown in this chapter. }\end{array}$ \\
\hline Monitoring & $\begin{array}{l}\text { The research team assured a proper monitoring along the entire process by continuously assuring } \\
\text { which step was being executed, how each step would feed the next, providing the necessary } \\
\text { guidance to the case company team and enacting continuously the action research cycle. }\end{array}$ \\
\hline
\end{tabular}

Table 9. Content of the eights steps of the action research process (Coughlan \& Coghlan, 2002) 


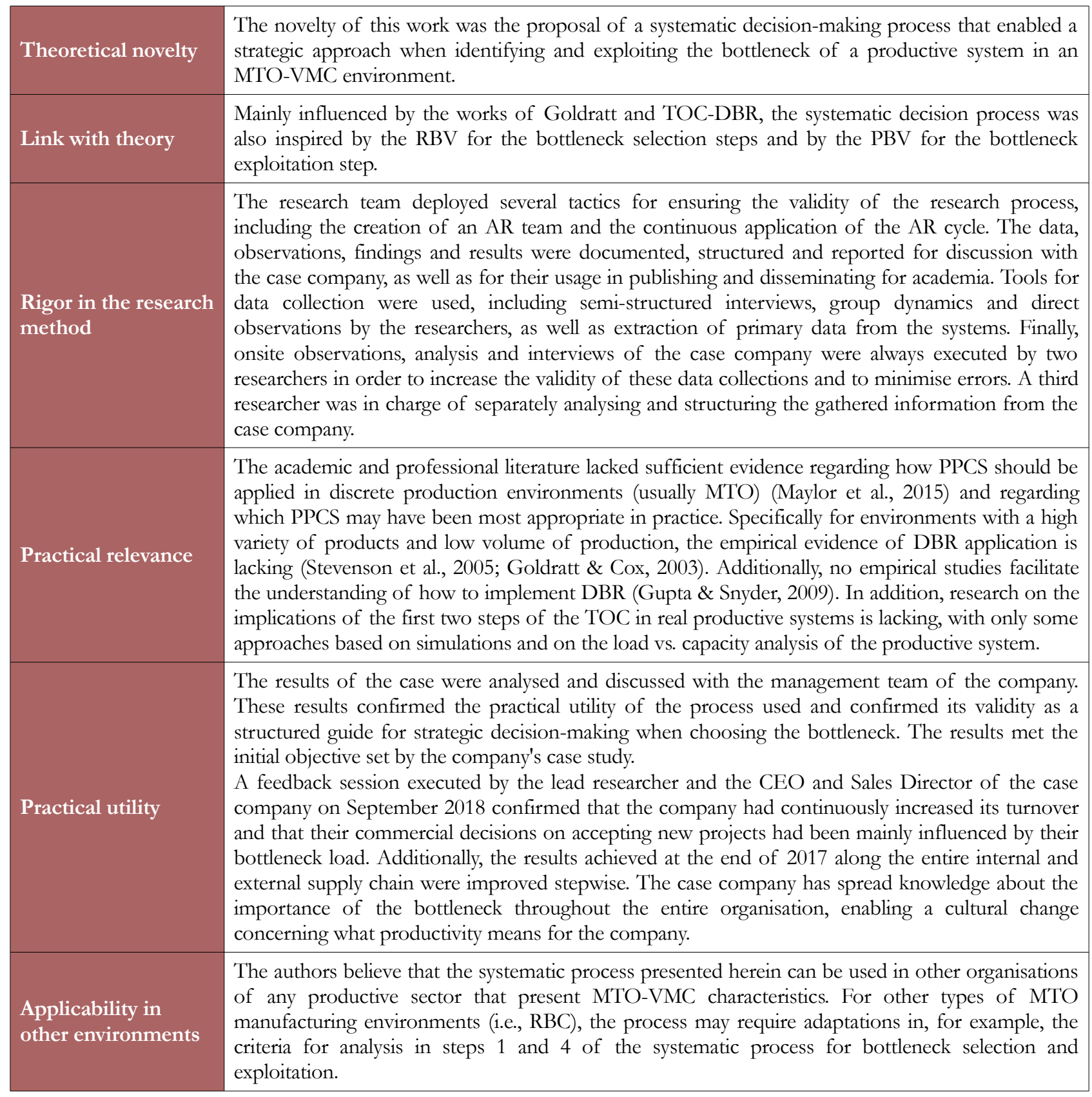

Table 10. Quality criteria for the research process

\section{Conclusion and Future Research}

The literature has recognised that MTO-VMC environments are complex in nature and difficult to manage in practice. This has also been observed by the researchers during their previous projects with other companies. The existing literature regarding the use of PPCS in these contexts is scarce and is mainly focused on serial manufacturing/make-to-stock. Few authors have suggested that the TOC-DBR PPCS could provide superior performance and an easy-to-use approach for MTO-VMC environments, and these proposals have been limited to simulation works. Therefore, empirical work in the industry is lacking. This kind of research could provide insights from the practice and embrace the complexity of PPCS implementation, as well as provide important theoretical checks and suggest relevant managerial implications. Additionally, since the theory presented in this investigation is at the early stage, the researcher must be out in the field and in close contact with the environment being studied (Handfield \& Melnyk, 1998). 
Based on the gap in the literature and the present research target, this work has three key contributions:

1. The specific four criteria to select the bottleneck, far beyond a load versus capacity perspective (i.e., providing a strategic perspective inspired by the main concepts from the RBV theory regarding the contribution of strategic resources to sustain competitive position);

2. A detailed discussion on how to exploit the bottleneck, which was aligned with the PBV theory and recognised that practices could also provide superior performance to organisations; and

3. The empirical test based on the presented case regarding how the systematic process containing the four criteria to select the bottleneck should be operatively applied to select and exploit bottlenecks according to some of Goldratt's seminal proposals. That systematic process has been successfully tested in the field on an MTO-VMC case company, and the research question regarding systematically selecting a bottleneck and exploiting it to enhance the competitive advantage/firm performance has been answered.

Linking seminal ideas from TOC-DBR and from the RBV and PBV is also of interest for this research field. Further necessary research should be performed on the relative importance of step 3 (bottleneck selection) versus step 4 (bottleneck exploitation) to gain competitive advantage/increase firm performance. In other words, further research must determine the importance of strategically selecting a bottleneck versus exploiting that critical resource. Works confronting these two factors could be of interest for academia and practitioners and could also contribute to the ongoing discussion of RBV versus PBV for operations management.

The implementation of TOC-DBR in the case company produced successful results in business terms, and the case company's top management was highly satisfied. These results may be of interest for practitioners acting in the MTO manufacturing context, since this proposal for selecting and exploiting the bottleneck not only affected results in operations management but also positively enabled an evolution of business turnover and profitability.

The research had obvious limitations linked to the nature of AR. Even though this type of research provides an in-depth picture of the studied cases, AR is specific to the context of action and does not aim to create universal knowledge (Coughlan \& Coghlan, 2002) even if it is important to understand the implications of the findings in other contexts (Eden \& Huxham, 1996; Coughlan \& Coghlan, 2002; Coghlan \& Brannick, 2014). The systematic process presented in this paper could be applicable within other organisations, especially after careful consideration of the particular manufacturing context (e.g., MTO-VMC or MTO-RBC).

Therefore, more case studies with in-depth perspectives would enrich theory-building concerning PPCS for MTO contexts. A logical immediate study would be testing the proposed systematic process in MTO-VMC companies in other sectors and in MTO-RBC companies. Additionally, testing the systematic procedure on engineering-to-order companies could reveal the generalizability of this research. Several aspects of steps 1 and 4 of the process could be influenced by the organisational context and the specific nature of each company.

\section{Declaration of Conflicting Interests}

The authors declared no potential conflicts of interest with respect to the research, authorship, and/or publication of this article.

\section{Funding}

The authors received no financial support for the research, authorship, and/or publication of this article.

\section{References}

Amaro, G., Hendry, L., \& Kingsman, B. (1999). Competitive advantage, customisation and a new taxonomy for non make-to-stock companies. International Journal of Operations \& Production Management, 19(4), 349-371.

https://doi.org/10.1108/01443579910254213

Barney, J. (1991). Firm Resources and Sustained Competitive Advantage. Journal of Management, 17(1), 99-120.

https://doi.org/10.1177/014920639101700108 
Berkley, J. (1992). A Review of the Kanban Production Control 2. I. Instantaneous Material Handling: Single-Card Systems, I(4), 393-411.

Borreguero-Sanchidrian, T., Pulido, R., Garcia-Sanchez, A., \& Ortega-Mier, M. (2018). Flexible Job Shop Scheduling With Operators in Aeronautical Manufacturing: A Case Study. IEEE Access, 6, 224-233. https://doi.org/10.1109/ACCESS.2017.2761994

Bromiley, P., \& Rau, D. (2014). Towards a practice-based view of strategy. Strategic Management Journal, 35(8), 1249-1256. https://doi.org/10.1002/smj.2238

Christopher, M., \& Towill, D.R. (2000). Supply chain migration from lean and functional to agile and customised. Supply Chain Management: An International Journal, 5(4), 206-213. https://doi.org/10.1108/13598540010347334

Coghlan, D., \& Brannick, T. (2014). Doing Action Research in Your Own Organization. Available at: https://bs2fmiv7w211.storage.googleapis.com/Egdfvtrbd8nbkIkfmn11.pdf

Coughlan, P., \& Coghlan, D. (2002). Action research for operations management. International Journal of Operations \& Production Management, 22(2), 220-240. https://doi.org/10.1108/01443570210417515

Cox, J.F., Blackstone, J.H., \& Schleier, J.G. (2003). Managing Operations: A Focus on Excellence. North River Press, Great Barrington.

Darlington, J., Francis, M., Found, P., \& Thomas, A. (2015). Design and implementation of a Drum-Buffer-Rope pull-system. Production Planning \& Control, 26(6), 489-504. https://doi.org/10.1080/09537287.2014.926409

Deming, W.E. (1982). Quality, productivity, and competitive position, 183. Available at: http://gpsinc.us/files/Deming.pdf

Dumond, E.J., \& Dumond, J. (1993). An Examination of Resourcing Policies for the $\backslash$ nMulti-resource Problem. International Journal of Operations \& Production Management, 13(5), 54-75. https://doi.org/10.1108/01443579310028175

Eden, C., \& Huxham, C. (1996). Action Research for Management Research. British Journal of Management, 7(1), 75-86. https://doi.org/10.1111/j.1467-8551.1996.tb00107.x

Gaury, E.G.A., Kleijnen, J.P.C., \& Pierreval, H. (2001). A methodology to customize pull control systems. Journal of the Operational Research Society, 789-799.

Goldratt, E.M. (1990). What is this thing called Theory of Constraints, and how should it be implemented? Available at: https://books.google.es/books?id=nUVaAAAAYAAJ\&hl=es\&source=gbs_book_other_versions

Goldratt, E., \& Cox, J. (2005). La Meta Un proceso de mejora continua. In The effects of brief mindfulness intervention on acute pain experience: An examination of individual difference, 3. https://doi.org/10.1017/CBO9781107415324.004

Goldratt, E.M., \& Cox, J. F. (2003). The Goal: Excellence in manufacturing. European Journal of Operational Research, 26(3), 412-413. https://doi.org/10.1016/0377-2217(86)90143-8

Goldratt, E.M., \& Fox, R.F. (1986). The Race. New York: North River Press.

Guan, Z., Peng, Y., Ma, L., Zhang, C., \& Li, P. (2008). Operation and control of flow manufacturing based on constraints management for high-mix/low-volume production. Frontiers of Mechanical Engineering in China, 3(4), 454-461. https://doi.org/10.1007/s11465-008-0083-5

Gupta, M., \& Snyder, D. (2009). Comparing TOC with MRP and JIT: A literature review. International Journal of Production Research, 47(13), 3705-3739. https://doi.org/10.1080/00207540701636322

Gupta, M., \& Boyd, L. (2008). Theory of constraints: a theory for operations management. International Journal of Operations \& Production Management, 28(10), 991-1012. https://doi.org/10.1108/01443570810903122

Handfield, R.B., \& Melnyk, S.A. (1998). The scientific theory-building process: a primer using the case of TQM. Journal of Operations Management, 16(4), 321-339. https:/ / doi.org/10.1016/S0272-6963(98)00017-5 
Lizarralde, A., \& Apaolaza Perez De Eulate, U. (2017). Optimization of the order-delivery process using the Theory of Constraints (TOC): A case study. Proceedings from the International Congress on Project Management and Engineering 2017, (July), 2543-2554. Cadiz: Proceedings from the International Congress on Project Management and Engineering.

Lizarralde, A., Apaolaza, U., \& Mediavilla, M. (2019a). Enfoque estratégico para la identificación de cuellos de botella en entornos de fabricación contra pedido y plantas tipo V: estudio de caso de DBR. Direccion y Organizacion, $67,46-51$.

Lizarralde, A., Apaolaza, U., \& Mediavilla, M. (2019b). Perspectivas Prácticas Desde La Industria Para La Identificación Del Cuello De Botella En Fábricas “Make-To-Order”: ¿Una Decisión Estratégica U Operativa? Dyna Ingenieria E Industria, 94(1), 507-511. https:/ / doi.org/10.6036/9070

Lockamy, A. (2013). Examining supply chain networks using V-A-T material flow analysis. Supply Chain Management: An International Journal. https://doi.org/10.1108/13598540810894924

Lockamy, A., \& Cox, F. (1995). An empirical study of division and plant performance measurement systems in selected world class manufacturing firms: linkages for competitive advantage. The International Journal of Production Research, 33(1), 221-236.

Mabin, V.J., \& Balderstone, S.J. (2003). The performance of the theory of constraints methodology: Analysis and discussion of successful TOC applications. International Journal of Operations \& Production Management, 23(6), 568-595. https://doi.org/10.1108/01443570310476636

Maccarthy, B.L., \& Fernandes, F.C.F. (2000). A multi-dimensional classification of production systems for the design and selection of production planning and control systems. Production Planning \& Control, 11(5), 481-496. https://doi.org/10.1080/09537280050051988

Manikas, A., Gupta, M., \& Boyd, L. (2015). Experiential exercises with four production planning and control systems. International Journal of Production Research, 53(14), 4206-4217. https://doi.org/10.1080/00207543.2014.985393

Mathur, G., Jugdev, K., \& Shing Fung, T. (2007). Intangible project management assets as determinants of competitive advantage. Management Research News, 30(7), 460-475. https://doi.org/10.1108/01409170710759694

Maylor, H., Turner, N., \& Murray-Webster, R. (2015). “It worked for manufacturing...!”: Operations strategy in project-based operations. International Journal of Project Management, 33(1), 103-115.

https://doi.org/10.1016/j.ijproman.2014.03.009

McNiff, J., \& Whitehead, J. (2009). Doing and writing action research. Sage Publications.

Naor, M., Bernardes, E.S., \& Coman, A. (2013). Theory of constraints: Is it a theory and a good one? International Journal of Production Research, 51(2), 542-554. https://doi.org/10.1080/00207543.2011.654137

Ohno, T. (1988). Toyota production system: beyond large-scale production. Available at: https://books.google.es/books?

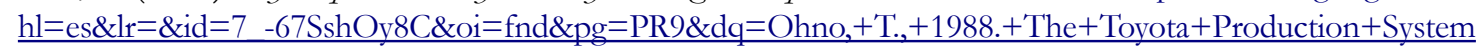
$\% 3 \mathrm{~B}+$ Beyond +Large-Scale+Production.Portland, $+\mathrm{OR}$ : +Productivity+Press.\&ots=YoSzBgyhC0\&sig=O0gvYpHtthe1CZKn7IQ8V5wW4Ho

Olhager, J., \& Rudberg, M. (2002). Linking manufacturing strategy decisions on process choice with manufacturing planning and control systems. International Journal of Production Research, 40(10), 2335-2351.

https://doi.org/10.1080/00207540210131842

Panizzolo, R. (2016). Theory of constraints (TOC) production and manufacturing performance. International Journal of Industrial Engineering and Management, 7(1), 15-23.

Pretorius, P. (2014). Introducing in-between decision points to TOC's five focusing steps. International Journal of Production Research, (November), 37-41. https://doi.org/10.1080/00207543.2013.836612 
Rabbani, M., \& Tanhaie, F. (2015). A Markov chain analysis of the effectiveness of drum-buffer-rope material flow management in job shop environment. International Journal of Industrial Engineering Computations, 6(4), 457-468. https://doi.org/10.5267/j.ijiec.2015.6.001

Rahman, S. (1998). Theory of constraints: a review of the philosophy and its applications. International Journal of Operations \& Production Management, 18(4), 336-355.

Romagnoli, G. (2015). Design and simulation of CONWIP in the complex flexible job shop of a Make-To-Order manufacturing firm. International Journal of Industrial Engineering Computations, 6(1), 117-134.

https://doi.org/10.5267/j.ijiec.2014.8.003

Ronen, B., \& Pass, S. (2008). Focused Operations Management: Doing More with Existing Resources. John Wiley \& Sons.

Spearman, M.L., \& Zazanis, M.A. (1992). Push and Pull Production Systems: Issues and Comparisons. Operations Research, 40(3), 521-532. https://doi.org/10.1287/opre.40.3.521

Stevenson, M., Hendry, L.C., \& Kingsman, B.G. (2005). A review of production planning and control: the applicability of key concepts to the make-to-order industry. International Journal of Production Research, 43(5), 869-898. https://doi.org/10.1080/0020754042000298520

Sultana, I., \& Ahmed, I. (2014). A state of art review on optimization techniques in just in time. Uncertain Supply Chain Management, 2, 15-26. https://doi.org/10.5267/j.uscm.2013.10.006

Suri, R. (1998). Quick response manufacturing: A company-wide approach to lead time reduction. Portland, OR: Productivity Press.

Susman, G.I., \& Evered, R.D. (1978). An Assessment of the Scientific Merits of Action Research. Administrative Science Quarterly, 23(4), 582-603.

Thürer, M., Stevenson, M., Silva, C., \& Qu, T. (2017). Drum-buffer-rope and workload control in High-variety flow and job shops with bottlenecks: An assessment by simulation. International Journal of Production Economics, 188(April), 116-127. https://doi.org/10.1016/j.ijpe.2017.03.025

Watson, K.J., Blackstone, J.H., \& Gardiner, S.C. (2007). The evolution of a management philosophy: The theory of constraints. Journal of Operations Management, 25(2), 387-402. https://doi.org/10.1016/j.jom.2006.04.004

Womack, J.P., Jones, D.T., \& Roos, D. (2008). The Macbine That Changed the World. Free Press.

Journal of Industrial Engineering and Management, 2020 (www.jiem.org)

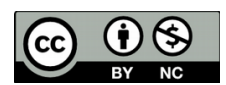

Article's contents are provided on an Attribution-Non Commercial 4.0 Creative commons International License. Readers are allowed to copy, distribute and communicate article's contents, provided the author's and Journal of Industrial Engineering and Management's names are included. It must not be used for commercial purposes. To see the complete license contents, please visit https://creativecommons.org/licenses/by-nc/4.0/. 